\title{
Pantothenate Kinase Associated Neurodegeneration in Two Brothers
}

\section{Neurodegeneração Associada a Pantotenato Quinase em Dois Irmãos}

Bruno Niemeyer de FREITAS RIBEIRO $\rrbracket^{1}$, Tiago MEDINA SALATA², Lívia de OLIVEIRA ANTUNES², Beatriz SALATA ANTUNES ${ }^{3}$

Acta Med Port 2015 Sep-Oct;28(5):674-674

Keywords: Neurodegenerative Diseases; Phosphotransferases (Alcohol Group Acceptor); Siblings.

Palavras-chave: Doenças Neurodegenerativas; Fosfotransferases (Aceptor do Grupo Álcool); Irmãos.

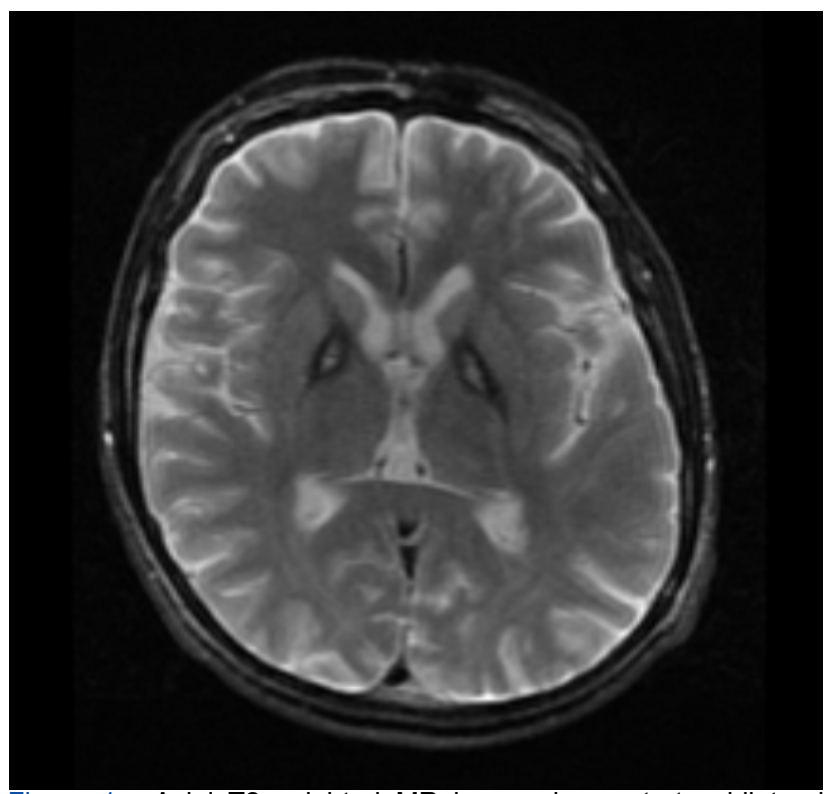

Figure 1 - Axial T2-weighted MR image demonstrates bilateral hyperintense pallidal areas on background areas of T2 shortening (eye-of-the-tiger sign)

Two male brothers, aged 28 and 26 years, children of outbred parents, presented neurological symptoms. The oldest developed progressive spasticity, dysarthria, and aggressiveness for the previous four years. Concurrently his brother showed orofacial dyskinesia and cognitive decline. Family history was unremarkable. Laboratory testing was normal, including ceruloplasmin, ferritin, syphilis serology and viral markers (HIV, HBV, HCV, HTLV-1); the peripheral blood smear was negative for acanthocytes. Ophthalmoscopy was normal. Brain magnetic resonance imaging (MRI) revealed the 'eye of the tiger' sign on coronal and axial T2-weighted

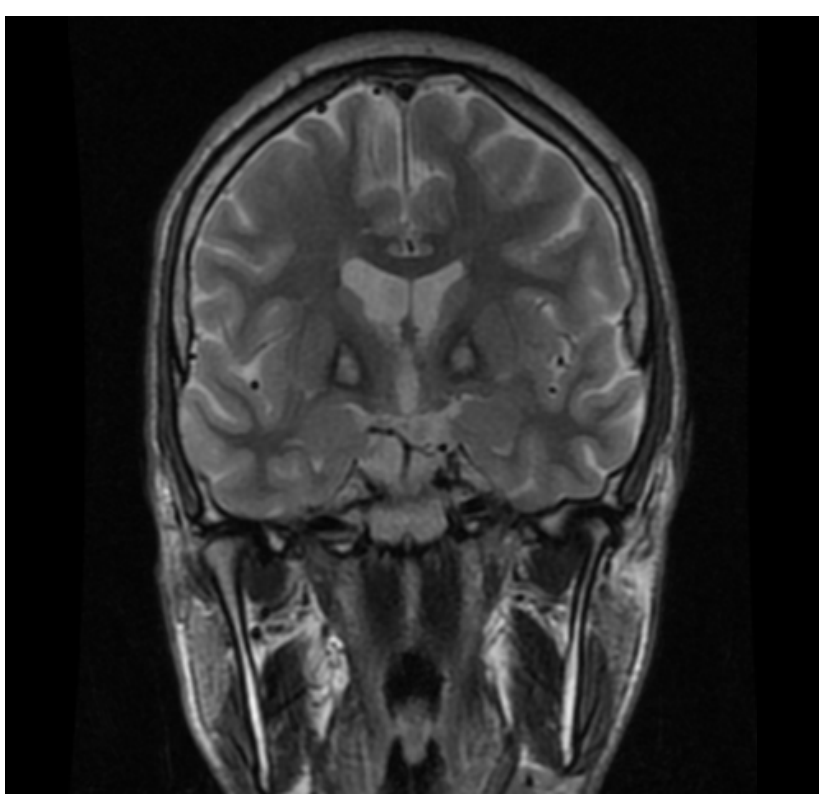

Figure 2 - Coronal T2-weighted MR image demonstrates bilateral hyperintense pallidal areas on background areas of T2 shortening (eye-of-the-tiger sign)

images in both cases (Fig. 1 older brother; Fig. 2, younger brother). Molecular genetic testing revealed the G521R mutation in the PANK2 gene.

Pantothenate kinase-associated neurodegeneration (PKAN) is a rare autosomal recessive disorder, and a form of neurodegeneration with brain iron accumulation (NBIA). ${ }^{1-}$ ${ }^{3}$ PKAN cases can be either classical, with onset in the first decade, or atypical, with late-onset, both presenting extrapyramidal dysfunction. ${ }^{1,3}$ The 'eye of the tiger' sign is the characteristic MRI finding. ${ }^{1-4}$

\section{REFERENCES}

1. Doi H, Koyano S, Miyatake S, Matsumoto N, Kameda T, Tomita A, et al. Siblings with the adult-onset slowly progressive type of pantothenate kinaseassociated neurodegeneration and a novel mutation, lle346Ser, in PANK2: clinical features and (99m) Tc-ECD brain perfusion SPECT findings. J Neurol Sci. 2010;290:172-6.

2. Guillerman P. The eye-of-the-tiger sign. Radiology. 2000;217:895-6.

3. Farage L, Castro MA, Macedo TA, Assis MC, Souza LP, Freitas LO. Síndrome de Hallervorden Spatz: achados na ressônancia magnética. Relato de caso. Arq Neuro-Psiquiatr. 2004:62:730-3.

4. Hegde AN, Mohan S, Lath N, Lim CC. Differential diagnosis for bilateral abnormalities of the basal ganglia and thalamus. Radiographics. 2011;31:5-30.

1. Clinic 3D Diagnóstico por Imagem. Hospital Casa de Portugal. Rio de Janeiro. Brasil.

2. Department of Radiology. Hospital Casa de Portugal. Rio de Janeiro. Brasil.

3. Universidade do Grande Rio. Rio de Janeiro. Brasil.

$\triangle$ Autor correspondente: Bruno Niemeyer de Freitas Ribeiro. bruno.niemeyer@hotmail.com.

Recebido: 22 de Dezembro de 2014 - Aceite: 15 de Março de 2015 | Copyright @ Ordem dos Médicos 2015 
Bruno Niemeyer de FREITAS RIBEIRO, Tiago MEDINA SALATA, Lívia de OLIVEIRAANTUNES, Beatriz SALATA ANTUNES

\section{Pantothenate Kinase Associated Neurodegeneration in Two Brothers}

Acta Med Port 2015:28:674-674

Publicado pela Acta Médica Portuguesa, a Revista Científica da Ordem dos Médicos

Av. Almirante Gago Coutinho, 151

1749-084 Lisboa, Portugal.

Tel: +351218428215

E-mail: submissao@actamedicaportuguesa.com

www.actamedicaportuguesa.com

ISSN:0870-399X | e-ISSN: 1646-0758

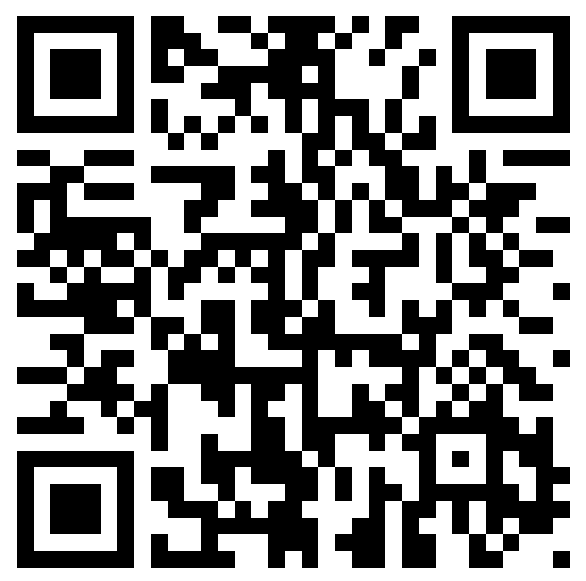

ACTA MÉDICA

PORTUGUESA 